\title{
Wood ash and microcrystalline cellulose (MCC) filled unsaturated polyester composites
}

\author{
Kadir KARAKUS ${ }^{1 *}$, İlkay ATAR ${ }^{1}$, İbrahim Halil BAŞBOĞA ${ }^{1}$, Fatma BOZKURT ${ }^{1}$, Fatih \\ MENGELOGLU ${ }^{1,2}$
}

\author{
${ }^{1 *}$ Faculty of Forestry, Dept. of Forest Industry Engineering, Kahramanmaraş, 46040, Turkey, \\ ${ }^{2}$ Graduate School of Natural and Applied Sciences, Dept. of Materials Science and Engineering, \\ Kahramanmaraş, 46040, Turkey. \\ *Corresponding author: karakus@ksu.edu.tr
}

Received Date: 13.03.2017

Accepted Date: 27.07.2017

\begin{abstract}
Aim of study: The objectives this research was determined the effects of wood ash and microcrystalline cellulose (MCC) filler on density and tensile, flexural and impact properties in the unsaturated polyester based composites.

Area of study: To determine the some properties of polyester based composites manufactured using different filler.

Material and Methods: In this study, polyester based composites were produced using wood ash and MCC as reinforcement agent. Polyester based composites were manufactured by casting method. During manufacturing process, cobalt and methyl ethyl ketone peroxide (MEKP) were used as accelerator and catalyser, respectively.

Main results: Wood ash provided better tensile strength compare to the MCC ones. Best tensile strength and elongation at break values were achieved with the use of $5 \%$ wood ash. In contrast, best tensile modulus results were obtained when MCC was utilized. In the case of flexural properties, both flexural strength and flexural modulus were reduced with the reinforcing agent concentration increase regardless of reinforcements type.
\end{abstract}

Research highlights: Density was increased with rising filler concentrations.

Keywords: Unsaturated polyesters, wood ash, microcrystalline cellulose (MMC), physical properties, mechanical properties.

\section{Odun Külü ve Mikrokristalin Selüloz İle Doldurulmuş Poliester Kompozitler}

\section{Özet}

Çalışmanın amacı: Doymamış polyester esaslı kompozit malzemelerin yoğunluk, çekme, eğilme ve darbe direnci özellikleri üzerine odun külü ve mikrokristalin selüloz oranının etkisinin belirlenmesi amaçlanmıştır.

Çalı̧̧ma alanı: Poliester esası kompozitlerde farklı dolgu maddeleri kullanılarak bazı özelliklerinin belirlenmesidir.

Materyal ve Yöntem: Bu çalısmada polimerik matris olarak doymamış poliester reçinesi kullanılırken dolgu maddesi olarak odun külü ve mikrokristalin selüloz kullanılmıştır. Poliester reçinesi esaslı kompozitler kast yöntemiyle üretilmiştir. Poliester reçinesi içerisine kobalt ve sertleştirici olarak Metil Etil Keton Peroksit (MEKP) ilave edilerek jel kıvamında olacak şekilde matris karışımı oluşturulmuştur.

Sonuçlar: Odun külü katılarak üretilen poliester reçinesi esaslı kompozitlerin çekme direnci değerleri mikrokristalin selüloz içeren kompozitlere göre daha iyi sonuçlar verdiği tespit edilmiştir. En iyi çekme direnci ve kopmada uzama değerinin $\% 5$ odun külü içeren kompozitlere ait olduğu belirlenmiştir. Çekmede elastikiyet modülünde ise en iyi sonucun mikrokristalin selüloz içeren kompozitlere ait olduğu görülmüştür. Odun külü ve mikrokristalin selüloz oranın artmasıyla kompozitlerin eğilme direnci ve eğilmede elastikiyet modülü değerlerinin azaldığı belirlenmiştir.

Araştırma vurguları: Dolgu maddesi oranın artmasıyla üretilen kompozitlerin yoğunluklarının arttığı tespit edilmiştir.

Anahtar kelimeler: Doymamış poliester reçinesi, odun külü, mikrokristalin selüloz, fiziksel özellikler, mekanik özellikler. 


\section{Introduction}

Wood polymer composites (WPC) is generally defined as a material produced with combination of lignocellulosic materials, polymer and other additives through different processing methods (Matuana and Heiden, 2004). Properties of the WPC strongly related to the type and structure of the lignocellulosic fiber/flour, polymer molecular weight, and presence of other fillers and modifiers (Mengeloğlu, 2006). WPC can be produced using thermoplastic and thermosetting polymers. Recently, utilization different additives in WPC manufacturing have gained tremendous attention. Epoxy, phenolic and unsaturated polyesters are principal examples of thermosetting polymers. Unsaturated polyester resins have cross-linking structure and these resins are the condensation products. Polyester resins are mixed with different fillers and reinforcements by using free radical initiators (Dholakiya, 2012). Unsaturated polyester based composites are usually manufactured with unsaturated polyester and fiberglass. Resulting material is called fiberglass reinforced plastic (FRP). Recently different lignocellulosic based fillers were utilized in unsaturated polyesters to produce composites. Several studies were conducted to investigate polyester based composite manufacturing and property determination.

Aziz and Ansell (2004) were studied the effect of alkali treated long and randomly distributed kenaf and hemp fibres. In another study, Aziz et al., (2005) successfully produced natural fibre filled polyester composites. Balcioğlu et al., (2012) determined the effect of walnut shell flour on the abrasion properties of polyester based composites. Sanusi et al., (2013) investigated the effect of wood ash on the some properties of composites produced from fibre glass and epoxy resin. Zhang et al., (2013) studied the adhesion between wood fiber and unsaturated polyester matrix.

Ricciardi et al., (2012) manufactured polyester based composites reinforced glass fibre and investigated thermal decomposition and fire behaviour of composites. In another study, Kushwaha et al., (2010) determined the physical and mechanical properties of the polyester composites filled bamboo and epoxy. There are needs further studies on natural filler reinforced polyester composites. In Turkey there is large amount of wood ash is available in biomass utilizing power plants. Successful application areas would serve both to environment and economy. Wood ash and microcrystalline cellulose (MCC) has been polymer matrix composites found to increase the some strength of polymer matrix composites.

In this study, polyester based composites were produced using wood ash as reinforcement agent. For comparison (MCC was also evaluated. Wood ash and MCC concentration was studied.

\section{Materials and Method}

\section{Materials}

Polyester (CE 92 N8) by CAMELYAF Resin industry \& trade LTD and microcrystalline cellulose (EMCOCEL) were used as polymeric matrix and filler, respectively. Wood ash was collected from the power plant of Kastamonu Integrated industry and trade limited company (Fig 1.) During manufacturing process, cobalt and methyl ethyl ketone peroxide (MEKP) were used as accelerator and catalyser, respectively (Fig 2.)

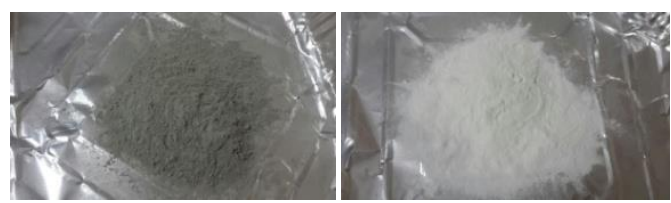

Figure 1. Wood ash and MCC

Polyester based composites were manufactured by casting method. Unsaturated polyester, cobalt and MEKP were mixed, poured into rectangular shape $(2 \times 175 \times 160$ $\mathrm{mm})$ mould and let drying for 24 hours. Test samples were cut from composites and conditioned $\left(65 \%\right.$ relative humidity and $\left.23^{\circ} \mathrm{C}\right)$ for 48 hours.

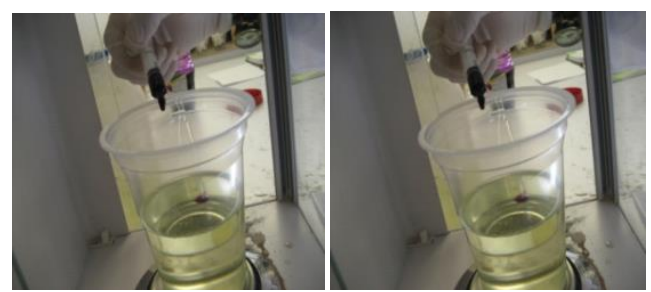

Figure 2. Polyester and MEKP 

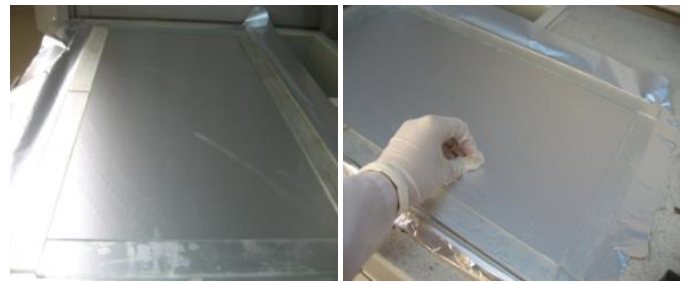

Figure 3. Rectangular shape mould

\section{Composites Testing}

In this study, ASTM standards were conducted for mechanical properties of manufactured polyester based composites. ASTM D 638, ASTM D 790 and ASTM D
256 were used for the tensile, flexural and impact tests using Zwick testing machine, respectively. Ten impact samples for each group were cut from the manufactured composites. Polytest notching cutter were used for the notches using a by RayRan ${ }^{\mathrm{TM}}$.

\section{Data Analysis}

Design-Expert ${ }^{\circledR}$ Version 7.0.3 statistical software program was used for statistical analysis. The effect of fillers loading on the physical and mechanical properties of the polyester based composite samples were evaluated.

Table 1. Experimental design

\begin{tabular}{l|c|c|c}
\hline \multicolumn{1}{c|}{ Formulations } & Polyester & Wood Ash & $\begin{array}{c}\text { Microcrystalline cellulose } \\
\text { (MCC) }\end{array}$ \\
\hline A & 100 & ---- & ---- \\
\hline B & 95 & 5 & ---- \\
\hline C & 980 & 10 & ---- \\
\hline D & 100 & ---- & --- \\
\hline E & 95 & ---- & 5 \\
\hline F & 90 & ---- & 10 \\
\hline
\end{tabular}

\section{Results and Discussion}

The effect of reinforcer type and concentration was investigated. Figure 4 represents the density of the polyester based composites. Y axis shows measured properties while $\mathrm{X}$ axis denoting the filler concentrations. Rectangular and triangle shapes present wood ash and MCC fillers, respectively

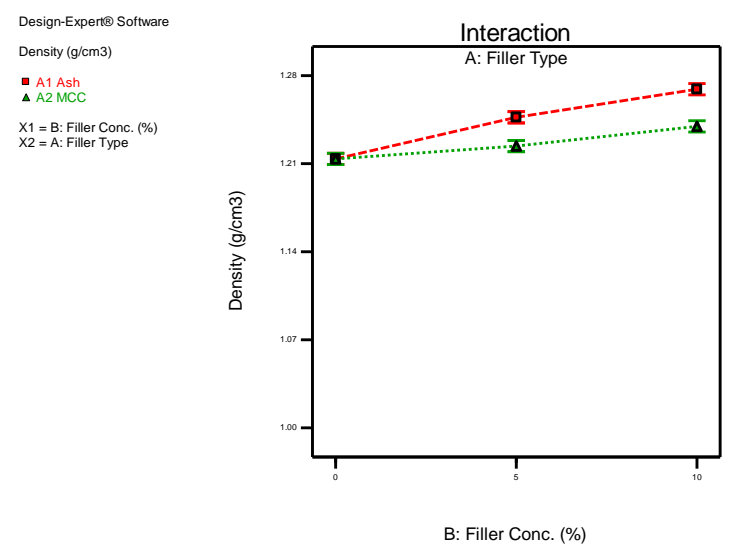

Figure 4. Interaction graph of filler type and filler content on density 
Densities of the manufactured composite were in the range of $1.21-1.28 \mathrm{~g} / \mathrm{cm}^{3}$. Interaction graph of density of the manufactured polyester composites was presented in Figure 1. Statistical analysis showed that both filler type and filler concentration had significant effect on density ( $P>0.0001$ and $P>0.0001$, respectively). Wood ash filled composites provided higher density values compared to MCC filled ones. In both filler type, density was increased with rising filler concentrations. Figure 5a shows the interaction graph of tensile strength. Statistical analysis showed that filler type had a significant effect on tensile strength (P: 0.0339). Wood ash (\%5) provided higher tensile strength compared to MCC filler. The tensile strength of composites manufactured with addition of 5\% wood ash was increased but were decreased with addition of more wood ash into polyester matrix. Similar results were also reported by others (Sanusi et al., 2013). Dabade et al., (2006) investigaed the effects of fiber lengths on tensile properties of hemp fiber/polyester composites. For MCC filled polyester composites, tensile strength values were similar results.

Figure $5 \mathrm{~b}$ and $5 \mathrm{c}$ represents the interaction graphs of tensile modulus and elongation at break values, respectively. Once again filler type had a significant effect on tensile modulus (P: 0.0223). However, for tensile modulus, MCC filler provided better properties compared to wood ash filled ones. The tensile modulus of polyester composite filled MCC were increased with filler concentrations. The tensile modulus of composites manufactured with addition of $5 \%$ wood ash was decreased but were increased with addition of more wood concentration into polyester matrix. In the case of elongation at break values, both filler type and filler concentration had significant effect $(\mathrm{P}<0.0001$ and P: 0.0016, respectively).

Interaction graphs of flexural strength and flexural modulus were given in Figure 6a and Figure 6b, respectively. Statistical analysis showed that filler type did not have significant effect on flexural strength (P: 0.3099). On the other hand, filler concentration had a significant effect on flexural strength $(\mathrm{P}<0.0001)$. Values were reduced with rising concentration of fillers.
MCC filling at higher concentration (\%10) provided higher flexural strength compared to wood ash filler. A similar effect was also reported by Dhakal (2007) for hemp fibre reinforced polyester composites. Also Khuswaha et al., (2010) used bamboo and glass fibre as reinforcement for polyester composites and found that fillers increased strength properties.

In flexural modulus, both filler type and filler concentration had significant effect on flexural modulus ( $\mathrm{P}$ : 0.0009 and $\mathrm{P}<0.0001$, respectively). It should be noted that wood ash filled composites provided higher modulus values at 5\% loading while MCC ones provided higher results at $10 \%$ filling. O'Dell (1997) were manufactured glass fiber and jute /polyester composites filled $10-15 \%$ fiber by using RTM technique. Mechanical properties of these composites were determined. Results showed that tensile and flexural strength of polyester composites reinforced jute fibers were half of those in glass fiber based composites. 
Design-Expert@ Software

TS (MPa)

- A1 Ash
$\triangle \mathrm{A} 2 \mathrm{MCC}$

X1 $=$ B: Filler Conc. $(\%)$
X2 $=$ A: Filler Type

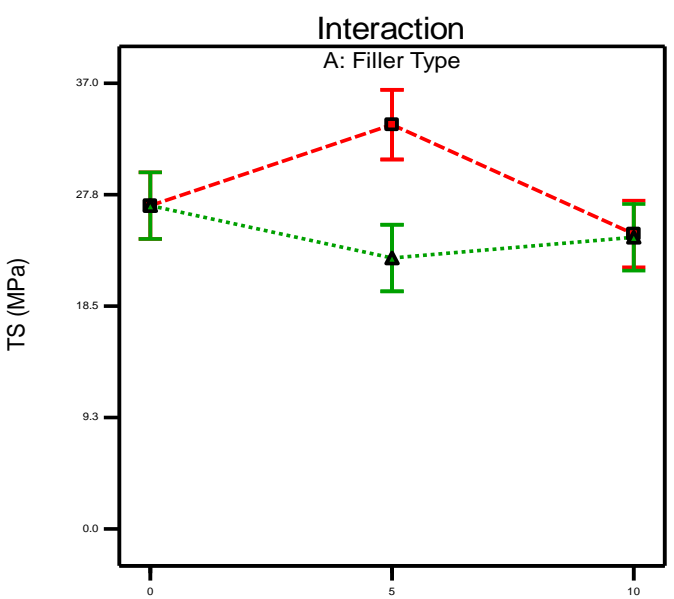

B: Filler Conc. (\%)

(a)

Design-Expert(i) Software

TM (MPa)

- A1 Ash
$\triangle \mathrm{A} 2 \mathrm{MCC}$

$\mathrm{X} 1=\mathrm{B}:$ Filler Conc. $(\%)$

nteraction

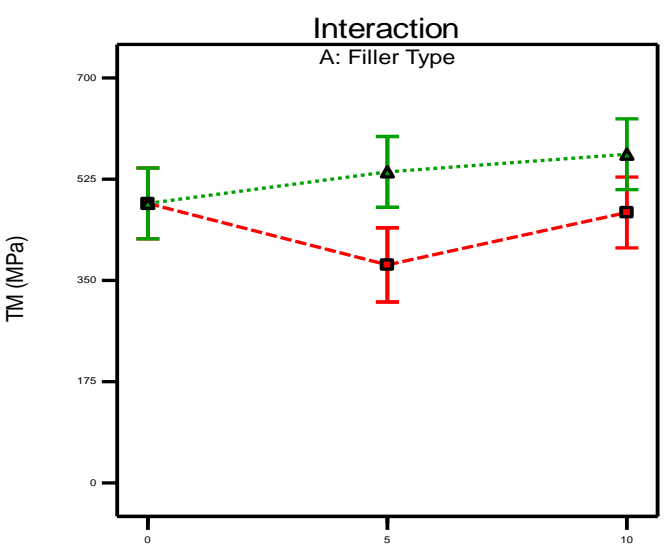

B: Filler Conc. (\%)

(b)
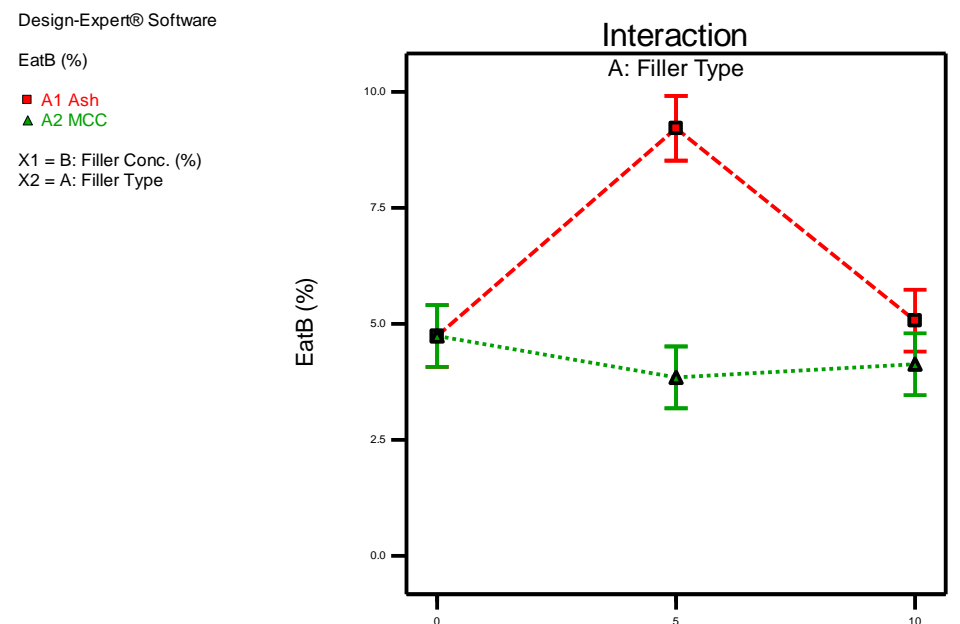

(c)

B: Filler Conc. (\%)

Figure 5. Interaction graph of filler type and filler content on tensile properties; a) tensile strength, b) tensile modulus and c) elongation at break. 

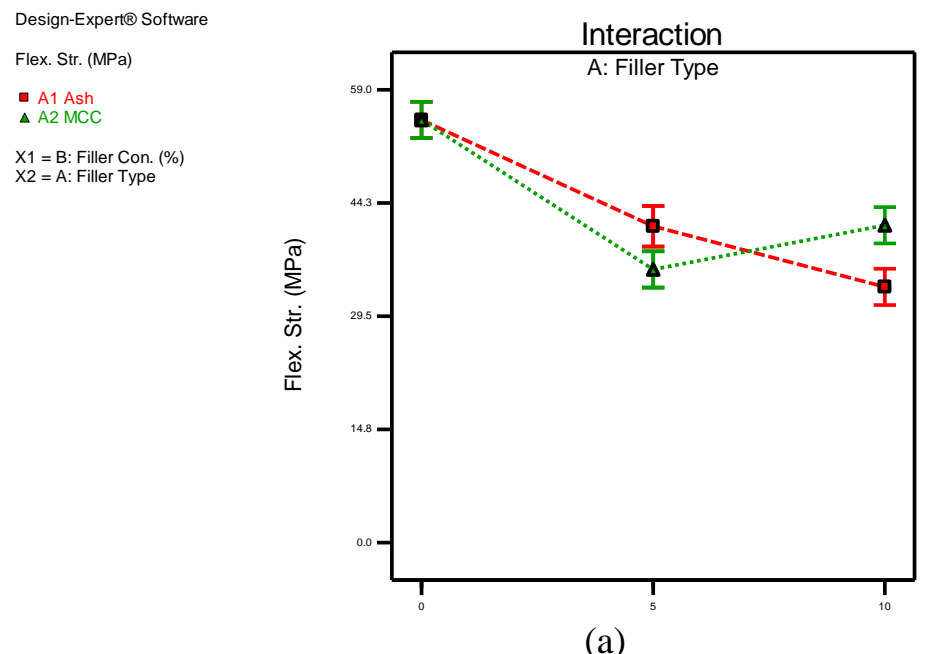

(a)

B: Filler Con. (\%)
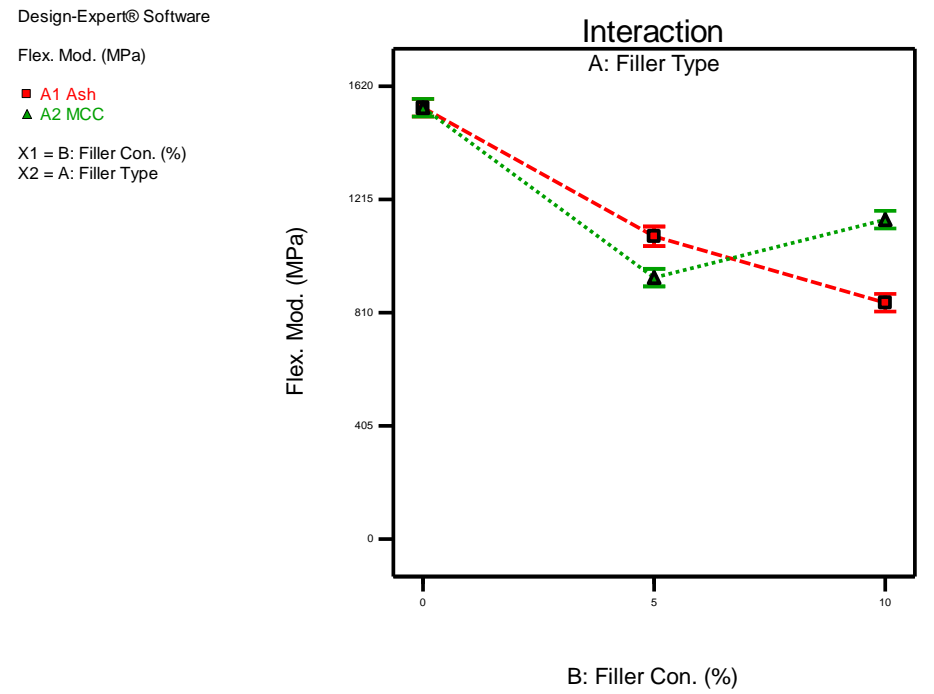

(b)

Figure 6. Interaction graph of filler type and filler content on flexural properties; a) flexural strength and b) flexural modulus

In the case of impact strength, interaction graph was given in Figure 7. Impact strength values were in the range of $0.75-2.28 \mathrm{~kJ} / \mathrm{m}^{2}$. Statistical analysis showed that filler type has significant effect on impact strength (P: 0.0499). This should be noted that it was not a strong effect. MCC filled ones provided higher impact strength values compared to wood ash filled ones (Singla and Chawla, 2010). In a similar study by Dhakal et al., (2007) were used to make nonwoven hemp fiber reinforced polyester composites. Filler concentration, on the other hand, did not have significant effect on impact strength in the concentration range (P: 0.3410). The results showed that impact strength of polymer composites manufactured with addition of $10 \%$ MCC was increased but were decreased with addition $10 \%$ wood ash concentration into polyester composites. Similar results were also reported by others. 


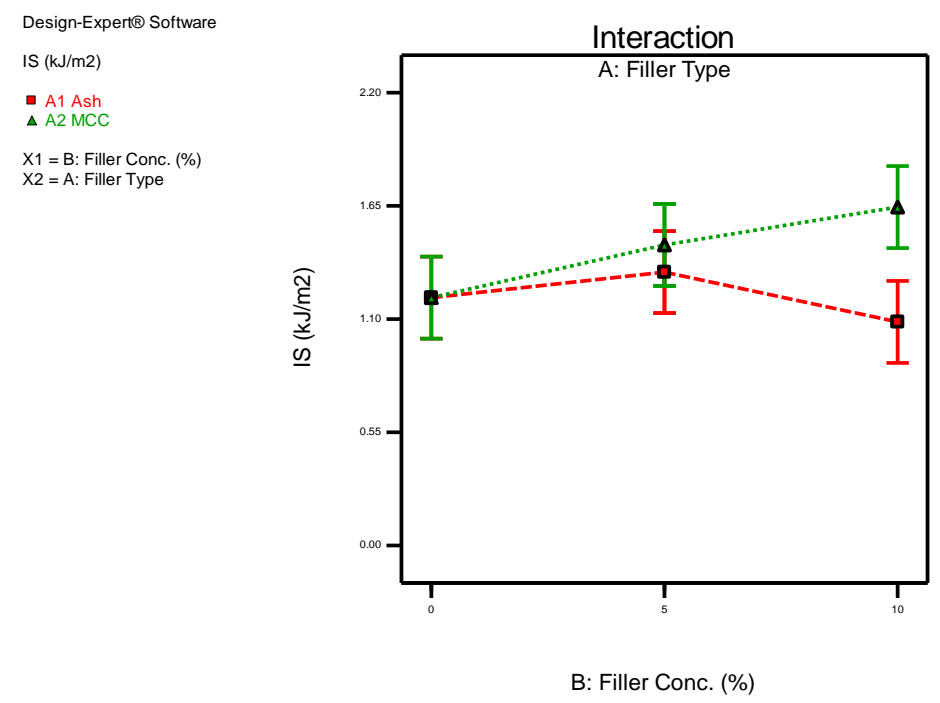

Figure 7. Interaction graph of filler type and filler content on impact strength

\section{Conclusion}

This study evaluated the effects of wood ash and MCC concentrations on the physical and mechanical properties of unsaturated polyester composites. Physical properties (density), mechanical properties (tensile, flexural, impact strength) were determined. Wood ash was successfully utilized as filler in polyester based composites. Wood ash provided better tensile strength compare to the MCC ones. Best tensile strength and elongation at break values were achieved with the use of 5\% wood ash. In contrast, MCC filled ones provided best tensile modulus results. Regardless of filler type, addition of filler reduced both flexural strength of flexural modulus. In addition, impact strength of the composites was not significantly affected by filler type and concentration. MCC ones provided slightly higher impact strength values compared to wood ash ones. Different natural fillers such as hemp, jute, banana, sisal, coir, kenaf, bamboo, rice, oil palm, and flax may be used to reinforcement in the polyester based composites. Chemical modification of fibers improved the interfacial properties. There is a need for future studies to investigate the effect of both filler chemical structure and their surface modification on the properties of polyester based composite.

\section{References}

Aziz, S.H., Ansell, M.P. (2004). The effect of alkalization and fibre alignment on the mechanical and thermal properties of kenaf and hemp bast fibre composites: Part 1- polyester resin matrix. Composites Science and Technology, 64 (9), 1219-1230.

Aziz, S.H., Ansell, M.P., Clarke, S.J., Panteny, S.R. (2005). Modified polyester resins for natural fibre composites. Composites Science and Technology, 65 (3-4), 525-535.

Balcıŏlu, H.E., Yeşil, Ö., Aktaş, M. (2012). Determination of abrasion resistance of walnut shell reinforced polyester resins. I. Ulusal Geri Kazanım Kongre ve Sergisi, 2-4 Mayıs, Uşak, Türkiye.

Dabade, B.M, Reddy, G.R, Rajesham, S. (2006). Effect of fiber length and fiber weight ratio on tensile properties of sun hemp and palmyra fiber reinforced polyester composites. Journal of Reinforced Plastics Composites, 25: 17331738.

Dhakal, H.N, Zhang, Z.Y, Richardson, M.O.W. (2007). Effect of water absorption on the mechanical properties of hemp fibre reinforced unsaturated polyester composites. Composites and Science Technology, 67: 1674-1683.

Dholakiya, B. (2012). Unsaturated polyester resin for specialty applications. Intech, Chapter 7 , http://dx.doi.org/10.5772/48479.

Matuana, L.M., Heiden, P.A. (2004). Wood composites. Encyclopedia of Polymer Science and Technology, 12: s. 521-546.

Mengeloğlu, F. (2006). Odun/termoplastik kompozitler. Polimerik Kompozitler 
Sempozyomu TBMOB Kimya Mühendisleri Odası, İzmir. Bildiriler Kitabı s. 471.

Kushwaha, P.K., Kumar, R. (2010). The studies on performance of epoxy and polyester-based composites reinforced with bamboo and glass fibers. Journal of Reinforced Plastics and Composites, 29 (13), 1952-1962.

O'Dell, J.L.O. (1997). Natural fibers in resin transfer molded composites. In: Fourth international conference on wood fiber plastic composites. Forest Product Society, Madison, WI, 280-285.

Ricciardi, M.R., Antonucci, V., Giordano, M., Zarrelli, M. (2012). Thermal decomposition and fire behavior of glass fiber- reinforced polyester resin composites containing phosphate-based fire-retardant additives.
Journal of Fire Sciences, 30 (4), 318-330.

Sanusi, O.M., Kofoworola, A., Jacob, O., Akindapo, O. (2013). Influence of wood ash on the mechanical properties of polymer matrix composite developed from fibre glass and epoxy resin, International Journal of Engineering Research and Technology (IJERT), 2 (12), 344-352.

Singla, M., Chawla, V. (2010). Mechanical properties of epoxy resin - fly ash composite. Journal of Minerals and Materials Characterization and Engineering, 9 (3), 199210.

Zhang, H, Cui, Y, Zhang, Z. (2013). Chemical treatment of wood fiber and its reinforced unsaturated polyester composites,. Journal of Vinyl Additives Technology, 19: 18-24 